Article

www.mdpi.com/journal/molecules

\title{
Solid-Phase Synthesis of Arylpiperazine Derivatives and Implementation of the Distributed Drug Discovery (D3) Project in the Search for CNS Agents
}

Pawel Zajdel ${ }^{1{ }^{1} *}$, Joanna Król ${ }^{1}$, Katarzyna Grychowska ${ }^{1}$, Maciej Pawłowski ${ }^{1}$, Gilles Subra ${ }^{2}$, Gaël Nomezine $^{2}$, Jean Martinez ${ }^{2}$, Grzegorz Satała ${ }^{3}$, Andrzej J. Bojarski ${ }^{3}$, Ziniu Zhou ${ }^{4}$, Martin J. O'Donnell ${ }^{4}$ and William L. Scott ${ }^{4, *}$

1 Department of Medicinal Chemistry, Jagiellonian University Medical College, 9 Medyczna Street, Kraków 30-688, Poland

2 Équipe Aminoacides Peptides et Protéines, Institut des Biomolécules Max Mousseron IBMM, UMR CNRS 5247, Faculté de Pharmacie, Université Montpellier I et II, 15 avenue Charles Flahault, Montpellier 34060, France

3 Department of Medicinal Chemistry, Institute of Pharmacology, Polish Academy of Sciences, 12 Smętna Street, Kraków 31-343, Poland

4 Department of Chemistry and Chemical Biology, Indiana University-Purdue University Indianapolis, Indianapolis, IN 46202, USA

* Authors to whom correspondence should be addressed; E-Mails: mfzajdel@cyf-kr.edu.pl (P.Z.); wscott@iupui.edu (W.L.S.).

Received: 13 April 2011; in revised form: 14 May 2011 / Accepted: 16 May 2011 / Published: 19 May 2011

Abstract: We have successfully implemented the concept of Distributed Drug Discovery (D3) in the search for CNS agents. Herein, we demonstrate, for the first time, student engagement from different sites around the globe in the development of new biologically active compounds. As an outcome we have synthesized a 24-membered library of arylpiperazine derivatives targeted to $5-\mathrm{HT}_{1 \mathrm{~A}}$ and $5-\mathrm{HT}_{2 \mathrm{~A}}$ receptors. The synthesis was simultaneously performed on BAL-MBHA-PS resin in Poland and the United States, and on BAL-PS-SynPhase Lanterns in France. The D3 project strategy opens the possibility of obtaining potent $5-\mathrm{HT}_{1 \mathrm{~A}} / 5-\mathrm{HT}_{2 \mathrm{~A}}$ agents in a distributed fashion. While the biological testing is still centralized, this combination of distributed synthesis with screening will enable a D3 network of students world-wide to participate, as part of their education, in the synthesis and testing of this class of biologically active compounds. 
Keywords: Distributed Drug Discovery (D3); combinatorial chemistry; solid-phase synthesis; SynPhase Lanterns; long-chain arylpiperazines; succinimides; 5-HT $1 \mathrm{~A} ; 5-\mathrm{HT}_{2 \mathrm{~A}}$ receptor affinity

Abbreviations: $\mathrm{CHCl}_{3}$ : chloroform; DCM: dichloromethane; DIC: $N, N$ '-diisopropylcarbodiimide; DIEA: diisopropylethylamine; DMF: dimethylformamide; HBTU: $O$-(1H-benzotriazol-1yl)-1,1,3,3-tetramethyluronium hexafluorophosphate; $\mathrm{SOCl}_{2}$ : thionyl chloride; TFA: trifluoroacetic acid.

\section{Introduction}

Arylpiperazines are valuable investigative tools in neuropsychopharmacology and have the potential to be leads in the development of new therapeutic agents. Flibanserin (Figure 1) is an excellent example of a classic long-chain arylpiperazine with an interesting new application. This meta-trifluorophenylpiperazine derivative, classified as a 5- $\mathrm{HT}_{1 \mathrm{~A}}$ agonist and 5- $\mathrm{HT}_{2 \mathrm{~A}}$ antagonist, had initially been developed as an antidepressant [1,2]. Later it was found that it exerts potential antipsychotic effects. It has also been investigated as a drug for women with decreased sexual desire [3].

Figure 1. Chemical structure of flibanserin.

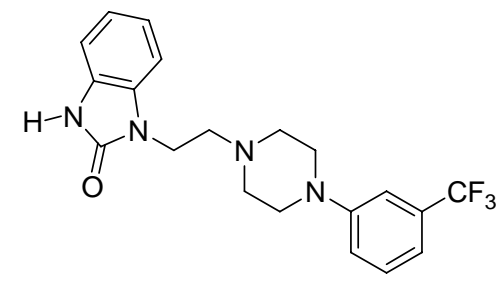

Previously we demonstrated that a member of an arylpiperazine library containing a cyclized $N$-acylated aspartic acid (PZ-68, Figure 2), was a partial agonist of 5- $\mathrm{HT}_{1 \mathrm{~A}}$ receptors and a $5-\mathrm{HT}_{2 \mathrm{~A}}$ antagonist, and showed in vivo antidepressant-like activity at doses of 5-20 mg/kg [4].

Figure 2. Chemical structure of PZ-68.

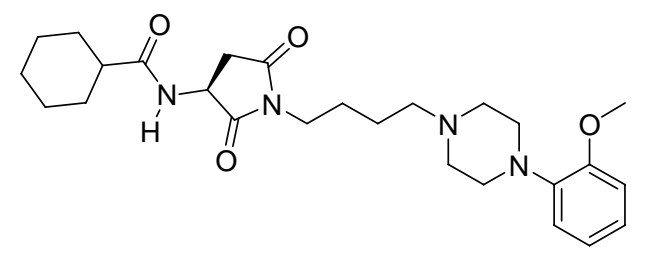

It is well known [5-7] that the affinity profile, functional activity and therapeutic potential (mostly antipsychotic, antidepressant, and/or anxiolytic) of arylpiperazine derivatives depends on the substitution pattern of the phenyl ring, linker length, and the terminal substructures. Accordingly, we designed a new series of meta-trifluoromethyl phenylpiperazine analogs of the most interesting previous sets containing $N$-acyl-3-aminopyrrolidine-2,5-diones and $N$-acylprolinamides. These molecules involved conformational restriction of a peptide unit in two ways: introduction of a cyclic 
amino acid (scaffold A, Figure 3), or an imide (scaffold B, Figure 3, resulting from an internal cyclization of aspartic acid). Based on our previous results [8], the structural modifications also varied both the linker length (three and four methylene groups) between the amide and the basic nitrogen atom of the arylpiperazine fragment, and the $\mathrm{R}^{2}$ acyl-substituents.

Figure 3. General structure of the target compounds $\mathbf{A}$ and $\mathbf{B}$ obtained via modification of the peptide unit 1 .

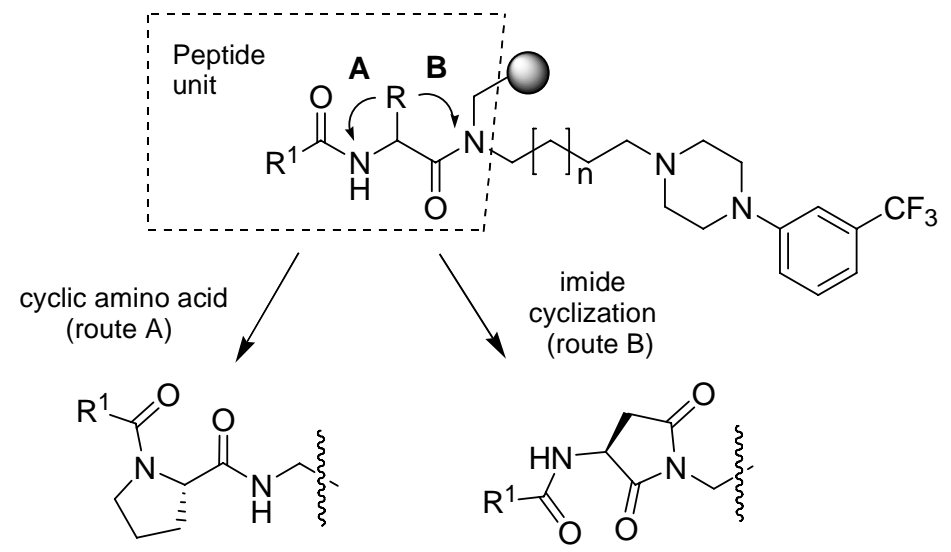

This work provided an opportunity to further enable the concept of Distributed Drug Discovery (D3) [9-11] by combining education, synthesis and biological screening. The chemistry required for SAR evaluation can be reproducibly carried out at distant sites, using simple and inexpensive equipment. Adding biological testing, even if centralized, with distributed synthesis engages students in the D3 network in these two key disciplines of drug discovery.

\section{Results}

\subsection{Library Synthesis}

A parallel solid-phase synthesis was carried out on two types of solid supports: BAL linker functionalized $p$-methylbenzhydrylamine (MBHA) polystyrene resin (1a) and BAL linker functionalized polystyrene SynPhase Lanterns (1b, Scheme 1).

The solid-phase chemistry on MBHA resin was adapted from the protocol reported on SynPhase Lanterns [9]. The separate, multiple syntheses on the resin were performed manually by using a Bill-Board set [10-13]. This equipment keeps the solid-phase reactions organized in a grid and simplifies repeated cycles of reactions, washing, cleavage, and the final solvent evaporation step. One compound was synthesized in each of the reaction vessels, which were organized on a solvent resistant $2 \times 3$ grid.

The syntheses began with the preparation of 4-(3-trifluoromethylphenyl)-1-piperazinylpropyl- and butylamine (2 $\{8\}$ and $2\{9\}$, Figure 4$)$. 
Scheme 1. Synthetic route to $\mathrm{N}$-acyl-3-aminopyrrolidine-2,5-diones and $\mathrm{N}$-acylprolinamides: (i) amine diversity reagents $2\{8,9\}[14], \mathrm{NaBH}_{3} \mathrm{CN}, 1 \%$ AcOH/DMF, rt, $24 \mathrm{~h}$; (ii) DIC, DMF, rt, 12 h, 2×; (iii) 20\% piperidine/DMF (iv) Diversity reagents 6\{1-6\}, HBTU, DIEA, DMF, RT, $3 \mathrm{~h}$ (series a) or $2 \mathrm{~h}$ (series b); (v) TFA $/ \mathrm{CHCl}_{3} / \mathrm{SOCl}_{2}, 35{ }^{\circ} \mathrm{C}, 12 \mathrm{~h}$ (series a) or $40{ }^{\circ} \mathrm{C}, 10 \mathrm{~h}$ (series b); (vi) TFA/ $\mathrm{CH}_{2} \mathrm{Cl}_{2}$, RT, $1.5 \mathrm{~h}$ (series a) or $1 \mathrm{~h}$ (series b). Synthesis of series a was carried out on BAL-MBHA-PS resin, while series b was synthesized on BAL-PS-Lantern. Chemset numbering (Figures 4 and 5) corresponds to the system applied in the historical libraries $[9,14,15]$.

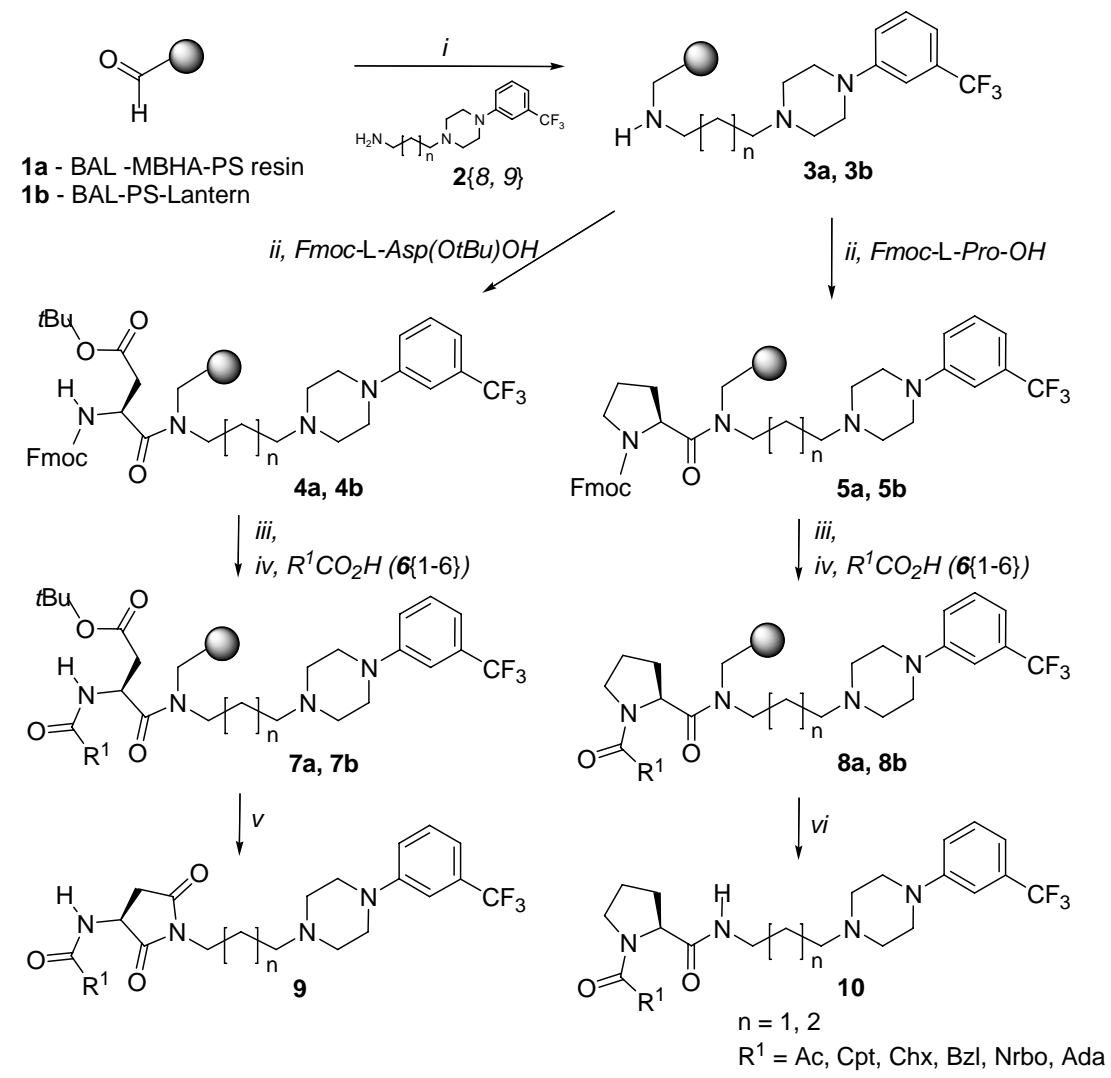

Figure 4. Diversity reagent 2. Amines $2\{8-9\}$ [14] used in the current project. Amines $2\{2-5\}$ were used to synthesize historical compounds $[9,15]$ presented for comparison in the radioligand binding experiments.
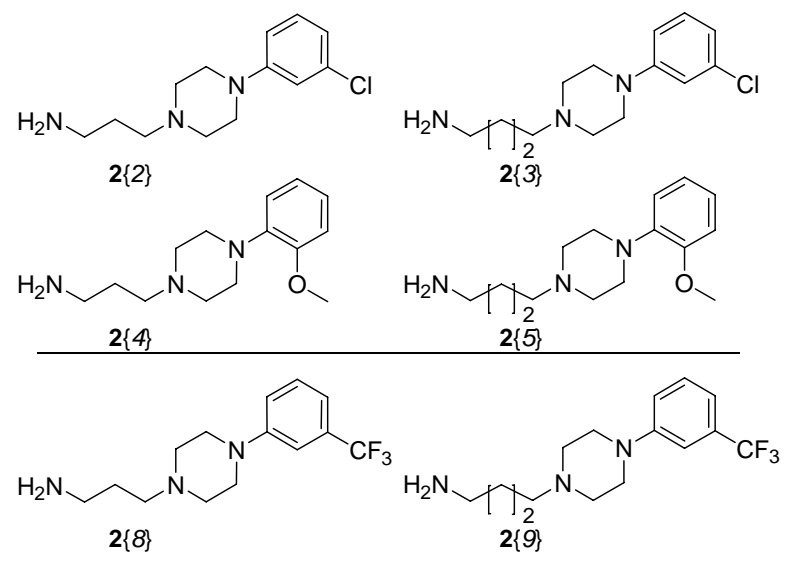
These amines were attached to the resin by a one-pot reductive amination to give the support-bound secondary amine products 3 . Fmoc-protected amino acids were then coupled to the support by a symmetric anhydride method using DIC in DMF to give chemsets 4 and 5. Following Fmoc removal, the amines were coupled with carboxylic acids (diversity reagents 6, Figure 5) in the presence of HBTU under basic conditions. The final pyrrolidine-2,5-dione derivatives 9 were obtained in a one-pot cleavage-cyclization step using a mixture of TFA $/ \mathrm{CHCl}_{3} / \mathrm{SOCl}_{2}$, while prolinamides $\mathbf{1 0}$ were obtained directly after treatment with $\mathrm{TFA} / \mathrm{CH}_{2} \mathrm{Cl}_{2}$.

Figure 5. Diversity of carboxylic acids $6\{1-6\}$.<smiles>CC(=O)O</smiles>

$6\{1\}$<smiles>O=C(O)C1CCCC1</smiles>

$6\{2\}$<smiles>O=C(O)C1CCCCC1</smiles>

$6\{3\}$<smiles>O=C(O)c1ccccc1</smiles>

$6\{4\}$<smiles>O=C(O)CC1CC2CCC1C2</smiles>

$6\{5\}$

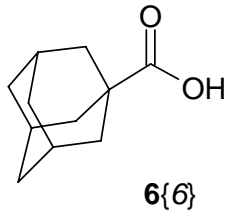

In parallel to solid-phase chemistry on the resin we have performed syntheses of selected library representatives on SynPhase Lanterns. This modular solid-support consists of soluble polymers grafted onto a rigid unreactive base polymer. As a tagging system for SynPhase Lanterns, we have used colored cogs and spindles (corresponding to the building block). At each step the Lanterns were manually sorted and pooled into separate vials containing respective reagents. Cleavage of the final products was performed in glass vials. The syntheses were conducted in standard laboratory glassware according to the protocol previously reported [9]. The crude purities of selected compounds synthesized in parallel on resin and Lanterns were determined and compared after removal of the cleavage cocktail (Table 1).

Table 1. Comparison of the analytical data for selected library members obtained from either resin or Lanterns.

\begin{tabular}{ccc||ccc}
\hline \multirow{2}{*}{ Compound } & \multicolumn{2}{c||}{ Purity $^{\text {a }}$} & \multirow{2}{*}{ Compound } & \multicolumn{2}{c}{ Purity $^{\text {a }}$} \\
\cline { 2 - 3 } & Lantern & Resin & & Lantern & Resin \\
\hline $\mathbf{9}\{8,3\}$ & 74 & 61 & $\mathbf{1 0}\{8,3\}$ & 96 & 93 \\
$\mathbf{9}\{8,4\}$ & 70 & 52 & $\mathbf{1 0}\{8,4\}$ & 94 & 93 \\
$\mathbf{9}\{8,5\}$ & 77 & 59 & $\mathbf{1 0}\{8,5\}$ & 96 & 87 \\
$\mathbf{9}\{9,3\}$ & 68 & 62 & $\mathbf{1 0}\{9,3\}$ & 97 & 97 \\
$\mathbf{9}\{9,4\}$ & 64 & 49 & $\mathbf{1 0}\{9,4\}$ & 98 & 89 \\
$\mathbf{9}\{9,6\}$ & 75 & 56 & $\mathbf{1 0}\{9,6\}$ & 98 & 86 \\
\hline
\end{tabular}

a Percent purity of the crude product was calculated on the peak area integration during HPLC analysis of cleaved compounds at a sum of wavelengths between 200 to $270 \mathrm{~nm}$.

All the compounds synthesized on the BAL-MBHA-PS resin were purified on silica gel (now using the reactor vessels to contain the silica for column chromatography) using DCM/MeOH (9/1 or 9/0.7, v/v) mixture. The percent purity was based on the peak area integration during HPLC analysis of cleaved compounds at a sum of wavelengths between 200 to $270 \mathrm{~nm}$ (Table 2). 
Table 2. Analytical data of the library.

\begin{tabular}{ccccc||ccccc}
\hline Compound & $\begin{array}{c}\mathbf{R}_{\mathbf{t}} \\
\text { (min) }\end{array}$ & Purity & $\begin{array}{c}\mathbf{M W} \\
\text { calc. }\end{array}$ & $\begin{array}{c}{[\mathbf{M}+\mathbf{H}]^{+}} \\
\text {found }\end{array}$ & Compd & $\begin{array}{c}\mathbf{R}_{\mathbf{t}} \\
\text { (min) }\end{array}$ & Purity $^{\mathbf{a}}$ & $\begin{array}{c}\mathbf{M W} \\
\text { calc. }\end{array}$ & $\begin{array}{c}\text { [M+ H] }^{+} \\
\text {found }\end{array}$ \\
\hline $\mathbf{9}\{8,1\}$ & 1.35 & 97 & 426.2 & 427.2 & $\mathbf{1 0}\{8,1\}$ & 1.34 & 99 & 426.2 & 427.3 \\
$\mathbf{9}\{8,2\}$ & 1.60 & 95 & 480.2 & 481.4 & $\mathbf{1 0}\{8,2\}$ & 1.62 & 99 & 480.3 & 481.0 \\
$\mathbf{9}\{8,3\}$ & 1.66 & 95 & 494.2 & 495.1 & $\mathbf{1 0}\{8,3\}$ & 1.69 & 96 & 494.3 & 495.2 \\
$\mathbf{9}\{8,4\}$ & 1.60 & 95 & 488.2 & 489.3 & $\mathbf{1 0}\{8,4\}$ & 1.58 & 96 & 488.2 & 489.8 \\
$\mathbf{9}\{8,5\}$ & 1.78 & 95 & 520.2 & 521.6 & $\mathbf{1 0}\{8,5\}$ & 1.82 & 96 & 520.3 & 521.5 \\
$\mathbf{9}\{8,6\}$ & 1.85 & 99 & 546.3 & 547.4 & $\mathbf{1 0}\{8,6\}$ & 1.90 & 97 & 546.3 & 547.4 \\
$\mathbf{9}\{9,1\}$ & 1.38 & 97 & 440.2 & 441.5 & $\mathbf{1 0}\{9,1\}$ & 1.37 & 93 & 440.2 & 441.5 \\
$\mathbf{9}\{9,2\}$ & 1.60 & 99 & 494.2 & 495.5 & $\mathbf{1 0}\{9,2\}$ & 1.60 & 96 & 494.3 & 495.1 \\
$\mathbf{9}\{9,3\}$ & 1.67 & 99 & 508.2 & 509.3 & $\mathbf{1 0}\{9,3\}$ & 1.68 & 97 & 508.3 & 509.3 \\
$\mathbf{9}\{9,4\}$ & 1.62 & 95 & 502.2 & 503.4 & $\mathbf{1 0}\{9,4\}$ & 1.58 & 97 & 502.2 & 503.3 \\
$\mathbf{9}\{9,5\}$ & 1.78 & 96 & 534.3 & 535.4 & $\mathbf{1 0}\{9,5\}$ & 1.80 & 98 & 534.3 & 535.6 \\
$\mathbf{9}\{9,6\}$ & 1.85 & 98 & 560.3 & 561.4 & $\mathbf{1 0}\{9,6\}$ & 1.86 & 96 & 560.3 & 561.1 \\
\hline
\end{tabular}

${ }^{a}$ Percent purity of the purified product was calculated on the peak area integration during HPLC analysis of cleaved compounds at a sum of wavelengths between 200 to $270 \mathrm{~nm}$.

\subsection{Biological Evaluation}

The affinity for serotonin $5-\mathrm{HT}_{1 \mathrm{~A}}$ and $5-\mathrm{HT}_{2 \mathrm{~A}}$ receptors of 13 selected library representatives was measured in vitro (Table 3, column 1) on the basis of the screening protocol described previously [9]. At the same time, the two well-known reference serotonin drugs buspirone and clozapine were examined, the obtained results being consistent with our previous data as well as with those reported in the literature (Table 3) [8].

Table 3. Radioligand binding data of synthesized compounds for 5- $\mathrm{HT}_{1 \mathrm{~A}}$ and $5-\mathrm{HT}_{2 \mathrm{~A}}$.

\begin{tabular}{|c|c|c|c|c|c|c|c|c|}
\hline \multirow{2}{*}{$\begin{array}{c}\text { Compound } \\
m-C_{3} \text { set }\end{array}$} & \multicolumn{2}{|c|}{$K_{\mathrm{i}}[\mathrm{nM}]^{\mathrm{a}}$} & \multirow{2}{*}{$\begin{array}{l}\text { Compound } \\
\text { m-Cl set }^{b}\end{array}$} & \multicolumn{2}{|c|}{$K_{\mathrm{i}}[\mathrm{nM}]$} & \multirow{2}{*}{\begin{tabular}{|c} 
Compd \\
o-OCH $_{3}$ set $^{\text {b }}$
\end{tabular}} & \multicolumn{2}{|c|}{$K_{\mathrm{i}}[\mathrm{nM}]$} \\
\hline & $5-\mathrm{HT}_{1 \mathrm{~A}}$ & $5-\mathrm{HT}_{2 \mathrm{~A}}$ & & $5-\mathrm{HT}_{1 \mathrm{~A}}$ & $5-\mathrm{HT}_{2 \mathrm{~A}}$ & & $5-\mathrm{HT}_{1}$ & $5-\mathrm{HT}_{2}$ \\
\hline $9\{8,1\}$ & 129 & 164 & $\mathbf{9}\{2,1\}^{\mathrm{c}}$ & $\mathrm{NT}^{\mathrm{e}}$ & NT & $\mathbf{9}\{4,1\}^{\mathrm{d}}$ & 480 & NT \\
\hline $9\{8,3\}$ & 170 & 276 & $\mathbf{9}\{2,3\}^{\mathrm{c}}$ & 360 & 92 & $\mathbf{9}\{4,3\}^{\mathrm{d}}$ & 230 & NT \\
\hline $9\{9,2\}$ & 24 & 79 & $9\{3,2\}$ & 28 & 47 & $\mathbf{9}\{5,2\}$ & 23 & 480 \\
\hline $\mathbf{9}\{9,3\}$ & 19 & 70 & $\mathbf{9}\{3,3\}$ & 26 & 6.5 & 9 \{. & 19 & 183 \\
\hline $\mathbf{9}\{9,4\}$ & 18 & 61 & $9\{3,4\}$ & 52 & 20 & $9\{5,4\}$ & 18 & 410 \\
\hline $\mathbf{9}\{9,5\}$ & 15 & 30 & & 21 & 4.2 & & 9 & 47 \\
\hline $\mathbf{9}\{9,6\}$ & 21 & 39 & $\mathbf{9}\{3,6\}$ & 47 & 25 & $\mathbf{9}\{5,6\}$ & 4 & 173 \\
\hline $\mathbf{1 0}\{8,4\}^{\mathrm{f}}$ & 122 & 898 & $\mathbf{1 0}\{2,4\}$ & NT & 875 & $\mathbf{1 0}\{4,4\}$ & NT & NT \\
\hline $\mathbf{1 0}\{8,6\}^{\mathrm{f}}$ & 42 & 1651 & $10\{2,6\}$ & 75 & 360 & $\mathbf{1 0}\{4,6\}$ & NT & NT \\
\hline $\mathbf{1 0}\{9,2\}^{\mathrm{f}}$ & 26 & 191 & $\mathbf{1 0}\{3,2\}^{\mathrm{c}}$ & NT & NT & $\mathbf{1 0}\{5,2\}$ & NT & NT \\
\hline $\mathbf{1 0}\{9,4\}^{\mathrm{f}}$ & 19 & 145 & $\mathbf{1 0}\{3,4\}$ & 78 & 128 & $\mathbf{1 0}\{5,4\}$ & NT & NT \\
\hline $\mathbf{1 0}\{9,5\}^{\mathrm{f}}$ & 10 & 82 & $\mathbf{1 0}\{3,5\}$ & 37 & 35 & $\mathbf{1 0}\{5,5\}$ & 14 & 547 \\
\hline $\mathbf{1 0}\{9,6\}^{\mathrm{f}}$ & 8 & 699 & $\mathbf{1 0}\{3,6\}$ & 13 & 140 & $\mathbf{1 0}\{5,6\}$ & 3 & 503 \\
\hline
\end{tabular}

${ }^{\text {a }}$ Estimated $K_{\mathrm{i}}$ values; as the reference drugs buspirone $\left(K_{\mathrm{i}}\left(5-\mathrm{HT}_{1 \mathrm{~A}}\right)=36 \mathrm{nM}\right)$ and clozapine $\left(K_{\mathrm{i}}\left(5-\mathrm{HT}_{2 \mathrm{~A}}\right)=6.05 \mathrm{nM}\right)$ we used; ${ }^{\mathrm{b}}$ Data taken from references [4] if not otherwise stated; ${ }^{\mathrm{c}}$ Data taken from reference [9]; ${ }^{\mathrm{d}}$ Data taken from reference [15]; ${ }^{\mathrm{e}} \mathrm{NT}=$ Not tested; ${ }^{\mathrm{f}}$ Proline amides from chemset $\mathbf{1 0}$ correspond to chemset $\mathbf{1 7}$ from historical libraries $[9,15]$. 


\section{Discussion}

The D3 program, developed at IUPUI to engage students in the discovery of new biologically active chemical entities, provided a framework to create a small international working group. The ultimate goal of the D3 project is to discover compounds for neglected diseases prevalent in developing countries. We wanted to demonstrate the successful application of the D3 process in the design, synthesis and biological evaluation, against 5-HT receptors, of this small library of arylpiperazine derivatives. The library design was based on our previously successful introduction of $N$-acylated amino acids fragments into the arylpiperazine moiety yielding potent $5-\mathrm{HT}_{1 \mathrm{~A}}$ and $5-\mathrm{HT}_{2 \mathrm{~A}}$ receptor ligands $[8,9,15,16]$. For the educational purpose, in the current project we chose a subset of analogs of the most interesting sets containing $\mathrm{N}$-acyl-3-aminopyrrolidine-2,5-diones and $\mathrm{N}$-acylprolinamides. We wished to enable students to further continue the structural modifications in the arylpiperazine fragment and differentiate the length of the alkyl spacer.

The library synthesis strategy was based on the previously developed solid-phase methodology performed on SynPhase Lanterns [9]. For the purpose of the D3 project we adapted the Lantern protocol to MBHA resin. Synthesis of the library on the resin beads was performed in Krakow and Indianapolis, while the modular Lantern solid supports were used in Montpellier. Average overall yields of the crude products, calculated on the basis of the initial loading of the solid support, were $50 \%$ to $69 \%$ and $35 \%$ to $58 \%$ for the resin and Lanterns, respectively. The crude purities of the compounds differed slightly among the laboratories. For the identified library members synthesized on the Lanterns the average purity was $76 \%$, while for compounds obtained from the resin the average purity was $69 \%$. Generally, Lanterns provided products with higher crude purities than the resin (Table 1). Within the series, the compounds bearing a proline residue (chemset 10) were always of higher purity. This is likely a function of the simple cleavage from the linker involving TFA.

To fulfill the quality standards for the combinatorial libraries and demonstrate compatibility with the D3 process, all 24 members were purified using the synthesis vessels now filled with silica gel as simple and inexpensive chromatography columns (Table 2). This enabled us to perform a distributed synthesis and to obtain replicated results by students from three sites around the globe: Jagiellonian University Medical College (Poland), University Montpellier, Biomolecules Institute Max Mousseron (France) and Indiana University-Purdue University Indianapolis (USA).

For the next stage of the project we selected 13 library representatives and tested them for their affinity for $5-\mathrm{HT}_{1 \mathrm{~A}}$ and $5-\mathrm{HT}_{2 \mathrm{~A}}$ receptors. Biological evaluation was also performed by students in the Polish Academy of Science. This is the first presentation of our synthetic cross-boundary efforts followed by biological evaluation of the new compounds within D3 project. The investigated compounds displayed low-to-good affinity for 5-HT $2 \mathrm{~A}$ receptors $\left(K_{\mathrm{i}}=1651\right.$ to $\left.30 \mathrm{nM}\right)$ and good-to-high affinity for $5-\mathrm{HT}_{1 \mathrm{~A}}$ receptors $\left(K_{\mathrm{i}}=170\right.$ to $\left.8 \mathrm{nM}\right)$ in in vitro binding experiments. Generally, compounds containing a four methylene spacer were more potent $5-\mathrm{HT}_{1 \mathrm{~A}}$ agents than their propylene counterparts, e.g., $\mathbf{9}\{8,3\}$ vs. $\mathbf{9}\{9,3\}$ and $\mathbf{1 0}\{8,4\}$ vs. $\mathbf{1 0}\{9,4\}$.

To continue the structure-activity relationship studies we compared the binding data of the new compounds (Table 3, column 1) with the historical data for the meta-chloro [4,9] and ortho-methoxy [4,15] analogs (Table 3, column 2 and 3). Replacement of the chlorine atom in the meta position of the phenyl ring with the more bulky trifluoromethyl substituent increased affinity of the new compounds 
for $5-\mathrm{HT}_{1 \mathrm{~A}}$ receptors. Interestingly, the $5-\mathrm{HT}_{1 \mathrm{~A}}$ receptor affinity of the compounds bearing a $m e t a-\mathrm{CF}_{3}$ substituent was comparable to the affinity of ortho- $\mathrm{OCH}_{3}$ derivatives (well-known 5- $\mathrm{HT}_{1 \mathrm{~A}}$ ligands). On the other hand, this modification decreased affinity of the new compounds for 5-HT $2 \mathrm{~A}$ receptors in comparison to their meta-chloro analogs. In opposite to ortho- $\mathrm{OCH}_{3}$ substituted pyrrolidine-2,5-dione derivatives, their meta-substituted analogs $\left(\mathrm{Cl}\right.$ and $\left.\mathrm{CF}_{3}\right)$ presented limited dependence of volume of cycloalkylcarbonyl fragment on $5-\mathrm{HT}_{1 \mathrm{~A}}$ receptor affinity; on the other hand, 5- $\mathrm{HT}_{1 \mathrm{~A}}$ receptor affinity of meta- $\mathrm{CF}_{3}$ prolinamides was clearly dependent on the kind of cycloalkyl substituent. It is worth noting that compounds containing the norborn-2-yl moiety in the cycloalkyl fragment were always the most potent $5-\mathrm{HT}_{2 \mathrm{~A}}$ agents.

\section{Experimental}

\subsection{General Methods}

Solution and solid-phase organic transformations, Lanterns and resin washes were carried out at ambient temperature, unless indicated otherwise. Organic solvents (from Acros Organics, Aldrich) were of reagent grade and were used without purification. PS-BAL linker SynPhase Lanterns with 38- $\mu$ mol loading were purchased from Mimotopes Pty, Australia. 4-Methylbenzhydrylamine hydrochloride resin (PL-MBHA·HCl, $1.6 \mathrm{mmol} / \mathrm{g}, 75-150 \mu \mathrm{m}$ ) was purchased from Polymer Laboratories. 4-(4-Formyl-3,5-dimethoxyphenoxy) butyric acid (BAL linker) was purchased from NovaBiochem. All the Fmoc amino acids and HBTU reagent were purchased from NovaBiochem and from Iris Chemicals. All other reagents were from Aldrich.

Purity of the synthesized compounds was confirmed by TLC performed on Merck silica gel $60 \mathrm{~F}_{254}$ aluminium sheets (Merck, Darmstadt, Germany). Spots were detected by their absorption under UV light $(\lambda=254 \mathrm{~nm})$. In all the cases HPLC technique was used as a routine.

Analytical HPLC were run on a Waters Alliance HPLC instrument, equipped with a Chromolith SpeedROD column $(4.6 \times 50 \mathrm{~mm})$. Standard conditions were eluent system A (water $/ 0.1 \% \mathrm{TFA})$, system B (acetonitrile/0.1\% TFA). A flow rate of $5 \mathrm{~mL} / \mathrm{min}$ and a gradient of $(0-100) \% \mathrm{~B}$ over $3 \mathrm{~min}$ were used. Detection was performed on a PDA detector. Retention times $\left(t_{\mathrm{R}}\right)$ are given in minutes.

Column chromatography was performed on silica gel (irregular particles 40-63 $\mu \mathrm{m}$ ) filled synthesis reactors. The yields of the final compounds, after chromatographic purification, were calculated on the basis of the initial loading of the starting resins and are the overall yields of all reaction steps starting from these resins.

${ }^{1} \mathrm{H}-\mathrm{NMR}$ and ${ }^{13} \mathrm{C}-\mathrm{NMR}$ spectra were recorded at $500 \mathrm{MHz}$ (Bruker Avance III 500) or $300 \mathrm{MHz}$ (Varian BB 200) spectrometer using TMS $(0.00 \mathrm{ppm})$ and chloroform- $d_{1}$, or chloroform- $d_{1}$ mixed with methanol- $d_{4}(2 \%-10 \%) ; J$ values are in Hertz $(\mathrm{Hz})$, and splitting patterns are designated as follows: $\mathrm{s}$ (singlet), d (doublet), $\mathrm{t}$ (triplet), $\mathrm{m}$ (multiplet).

Electrospray ionization mass spectrometry was conducted using a PESciex API III triple stage quadrupole mass spectrometer or Waters Alliance 2690 HPLC, coupled to a Micromass (Manchester, UK) Platform II spectrometer (electrospray ionization mode) operated in either positive-ion or negative-ion detection mode. Samples were prepared in acetonitrile/water $(50 / 50 \mathrm{v} / \mathrm{v})$, containing a $0.1 \%$ TFA. All the analyses were carried out using a C18 Xterra MS, $2.1 \times 30 \mathrm{~mm}$ column. 
A flow rate of $500 \mu \mathrm{L} / \mathrm{min}$ and a gradient of $(0-100) \%$ B over 5 min were used. Eluent A: water $/ 0.1 \%$ TFA; eluent $\mathrm{B}$ : acetonitrile/ $0.1 \%$ TFA. Positive ion electrospray mass spectra were acquired at a solvent flow rate of $100-500 \mu \mathrm{L} / \mathrm{min}$. Nitrogen was used for both the nebulizing gas and the drying gas. The data were obtained in a scan mode ranging from 400 to $1400 \mathrm{~m} / \mathrm{z}$ in $0.1 \mathrm{~s}$ intervals; 10 scans were summed up to get the final spectrum.

\subsection{General Procedures for Manual Solid-Phase Reactions}

Manual solid-phase organic syntheses at ambient temperature were carried out in several types of reaction vessels: $50 \mathrm{~mL}$ peptide synthesis reaction vessels with coarse porosity fritted glass support and supplied with a GL thread and a Teflon lined PBT screw cap (ChemGlass, CG-1860-03) were used for large scale (up to $3.7 \mathrm{mmol}$ ) reactions. Small scale reactions (typically $50 \mu \mathrm{mol}$ ) were performed in $3.5 \mathrm{~mL}$ fritted glass reaction vessels equipped with polypropylene screw caps with Teflon faced silicon septa on the Bill-Board set [13], which was designed by one of us (WLS) as inexpensive equipment to simplify and expedite multiple, manual solid-phase syntheses. The Bill-Board reaction vessel components are available from Chem-Glass: IUP-0305-270H for $3.5 \mathrm{~mL}$ reaction vessel; IUP-0305-280H (polypropylene screw cap); CV-4080-0013 (Teflon faced silicone septa).

For agitation purpose, the large scale reactions in the peptide synthesizers were placed on an orbital shaker Roto Mix while motor rotators were used for small scale reactions. Resin-bound intermediates were air-dried after the final $\mathrm{CH}_{2} \mathrm{Cl}_{2}$ washes, unless they needed to be re-weighed in which case overnight drying under high vacuum $(\leq 2 \mathrm{~mm})$ or under low vacuum over $24-36 \mathrm{~h}$ in a vacuum desiccator was carried out. During wash of the resin with solvents in the reaction vessels, at least $3 \mathrm{~min}$ of gravity draining was used for large scale whereas at least 30 seconds is needed for small scale followed by air-push.

BAL linker polystyrene SynPhase Lanterns with 38- $\mu$ mol loading, and colored tagging system were from Mimotopes (Clayton, Australia) [17]. To manually manage the library construction, a split-and-pool approach was chosen. The Lanterns were equipped with colored cogs and spindles (corresponding to building blocks) producing a visual tagging system. Solid-phase manipulations involving SynPhase Lanterns were carried out in a glass reaction vessels capped with silicone caps. As a standard the Lanterns were washed with respective solvents by immersing them in DMF $(3 \times 5 \mathrm{~min}), \mathrm{MeOH}(1 \times 5 \mathrm{~min})$, and $\mathrm{CH}_{2} \mathrm{Cl}_{2}(3 \times 5 \mathrm{~min})$, respectively. A single $200-\mathrm{mL}$ standard Schott flask equipped with a drilled topper was used. The Lanterns were allowed to air-dry for 15 min after the last $\mathrm{CH}_{2} \mathrm{Cl}_{2}$ washing.

\subsection{Solid-Phase Synthesis on BAL-MBHA-PS Resin}

Preparation of BAL-MBHA-PS Resin (1a, Scheme 1): MBHA HCl-PS resin (0.469 g, 0.75 mmol, $1.6 \mathrm{mmol} / \mathrm{g}$ ) loaded in a $25 \mathrm{~mL}$ peptide synthesis reaction vessel was sequentially washed with DMF $(3 \times 8 \mathrm{~mL}), \mathrm{CH}_{2} \mathrm{Cl}_{2}(2 \times 8 \mathrm{~mL}), 10 \%$ DIEA/ $\mathrm{CH}_{2} \mathrm{Cl}_{2}(5 \times 8 \mathrm{~mL})$ and $\mathrm{CH}_{2} \mathrm{Cl}_{2}(2 \times 8 \mathrm{~mL})$. A solution of 4-(4-formyl-3,5-dimethoxyphenoxy)butyric acid (0.805 g, $3.00 \mathrm{mmol}, 4$ equiv.), HBTU (1.138 g, $3.00 \mathrm{mmol}, 4$ equiv.) and DIEA (1.05 mL, $6.00 \mathrm{mmol}, 8$ equiv.) in anhydrous DMF prepared 5 min before was then added to the washed resin. The reaction vessel was put on the orbital shaker and allowed to shake at room temperature for $18 \mathrm{~h}$. The completion of the reaction was monitored by 
Chloranil test. The resultant orange yellow MBHA-BAL-PS resin (1a) was washed with DMF $(3 \times 8 \mathrm{~mL})$, $\mathrm{CH}_{2} \mathrm{Cl}_{2}(4 \times 8 \mathrm{~mL})$, and dried under low vacuum for $24 \mathrm{~h}$.

\subsubsection{Procedure for preparation of amine-bound Resin $\mathbf{3 a}, \mathbf{3} \mathbf{b}$ via reductive amination}

The resin $(0.9 \mathrm{~g}, 1.44 \mathrm{mmol})$ was divided into two reactors containing a suspension of sodium cyanoborohydride $\left(\left[\mathrm{NaBH}_{3} \mathrm{CN}\right]=0.23 \mathrm{~g}, 3.6 \mathrm{mmol}, 5\right.$ equiv.) and the amine ([Diversity reagent 2, $\mathbf{2}\{8,9\}]=3.6$ mmol, 5 equiv., Figure 1), in a $1 \%$ acetic acid in $20 \mathrm{~mL}$ of DMF. The reactors were shaken on for 24 hours at room temperature. Then the resin was drained. The resin was first washed with $10 \% \mathrm{AcOH}$ in DMF $(1 \times 5 \mathrm{~mL})$ then with DMF $(3 \times 8 \mathrm{~mL})$ and $\mathrm{CH}_{2} \mathrm{Cl}_{2}(4 \times 8 \mathrm{~mL})$, and dried under low vacuum.

\subsubsection{Coupling of amine resin 3a, $\mathbf{3 b}$ with $N$ - $\alpha$-Fmoc-Asp(OtBu)-OH and $N$ - $\alpha$-Fmoc-proline}

Two DMF solutions $(24 \mathrm{~mL})$ containing a Fmoc-protected amino acid and DIC each, were freshly prepared in a standard Schott flask before acylation ([Fmoc-AA-OH] $=3.6 \mathrm{mmol}, 5$ equiv, $[\mathrm{DIC}]=1.8 \mathrm{mmol}$, 2.5 equiv.), and the mixture was left for $15 \mathrm{~min}$ to form an active anhydride. Then $2 \mathrm{~mL}$ of the preactivated solutions were added to the resin and shaken for $12 \mathrm{~h}$ at a room temperature. The resin was drained and was washed following with DMF $(3 \times 8 \mathrm{~mL})$ and $\mathrm{CH}_{2} \mathrm{Cl}_{2}(4 \times 8 \mathrm{~mL})$, and dried under low vacuum. The acylation was repeated one more time for $12 \mathrm{~h}$.

\subsubsection{Standard Fmoc-deprotection protocol}

The Fmoc-deprotection step was carried out by treating the resin with a mixture of piperidine and DMF $(20 / 80 ; \mathrm{v} / \mathrm{v})$ for $3 \mathrm{~min}$. Then the resin was drained and the piperidine treatment was repeated for next 15 minutes. After removal of the deprotection solution, the Fmoc-deprotected resins were washed with DMF $(3 \times 8 \mathrm{~mL})$ and $\mathrm{CH}_{2} \mathrm{Cl}_{2}(4 \times 8 \mathrm{~mL})$, and dried under low vacuum for $12 \mathrm{~h}$.

\subsubsection{Acylation with carboxylic acids using HBTU}

The resins 4, 5 (31mg, $0.05 \mathrm{mmol}$ ) were swelled in DCM (5 mL) for $20 \mathrm{~min}$, and then washed with $\mathrm{DCM} / \mathrm{DMF}(80 / 20 ; \mathrm{v} / \mathrm{v})$. A solution of respective carboxylic acid $\left[\mathrm{R}^{2}-\mathrm{COOH}\right]=0.25 \mathrm{mmol}, 5$ equiv. (Figure 5: Diversity reagent $6\{1-6\})$ was then added to the reactor, followed by HBTU $(0.25 \mathrm{mmol}$, 5 equiv.) and DIEA ( $0.5 \mathrm{mmol}, 10$ equiv.). The solutions were added to the resin and the reactors were shaken for $3 \mathrm{~h}$ at room temperature. The resins were drained, and were washed with DMF $(3 \times 8 \mathrm{~mL})$, $\mathrm{CH}_{2} \mathrm{Cl}_{2}(4 \times 8 \mathrm{~mL})$, and dried under low vacuum for $24 \mathrm{~h}$. The procedure described above was repeated.

\subsubsection{Succinimide derivatives formation via cleavage and intramolecular ring closure}

Supported chemsets $7 \mathbf{a}, \mathbf{7 b}$ were placed in glass vials containing a $2 \mathrm{~mL}$ mixture of $\mathrm{TFA} / \mathrm{CHCl}_{3} /$ $\mathrm{SOCl}_{2}(50 / 50 / 1.5, \mathrm{v} / \mathrm{v} / \mathrm{v})$. The reaction was allowed to stand for $12 \mathrm{~h}$ at $35^{\circ} \mathrm{C}$. Then the solutions were filtered through the cotton via a Pasteur pipette to the evaporation vials fitted on Bill-Board. The "cocktail" was then evaporated by nitrogen flow used with Bill-Board evaporator. 
4.3.6. Cleavage of the proline derivatives off the resin

A $500 \mu \mathrm{L}$ of the TFA/DCM (80/20; v/v) was dispensed into glass vials containing the resin $\mathbf{8 a}, \mathbf{8 b}$. Cleavage was carried out at room temperature for $90 \mathrm{~min}$. The cleavage cocktail was removed from the Bill-Board glass vials under nitrogen flow.

\subsection{Analytical Data for Biologically Tested Library Members Synthesized on MBHA Resin}

$N-((S)-1-\{3-[4-((3-t r i f l u o r o m e t h y l)$ phenyl)piperazin-1-yl]propyl\}pyrrolidin-2,5-dion-yl)acetamide $\quad[9\{8,1\}]$. Yield: $13 \mathrm{mg}$ (59\% isolated yield) as a yellow oil following chromatographic purification over silica gel with $\mathrm{CH}_{2} \mathrm{Cl}_{2} / \mathrm{MeOH}$ (9:1); initial LC/MS purity 73\%, $t_{\mathrm{R}}=1.35 \mathrm{~min} .{ }^{1} \mathrm{H}-\mathrm{NMR}\left(300 \mathrm{MHz}, \mathrm{CDCl}_{3}\right.$ ): $\delta 1.42-1.54(\mathrm{~m}, 2 \mathrm{H}), 2.04(\mathrm{~s}, 3 \mathrm{H}), 2.61-2.69$ (dd, $J=18.5 \mathrm{~Hz}, J=4.9 \mathrm{~Hz}, 1 \mathrm{H}), 2.89(\mathrm{~m}, 2 \mathrm{H}), 3.06-3.19$ (m, 1H), 3.24-3.39 (m, 4H), 3.56-3.75 (m, 6H), 4.83-4.88 (m, 1H), 7.05-7.09 (d, J=8.2 Hz, 1H), $7.11(\mathrm{~s}, 1 \mathrm{H}), 7.21-7.25(\mathrm{~d}, J=7.7 \mathrm{~Hz}, 1 \mathrm{H}), 7.38-7.44(\mathrm{t}, J=7.9 \mathrm{~Hz}, 1 \mathrm{H}), 7.49-7.51(\mathrm{~d}, J=7.9 \mathrm{~Hz}$, 1H). MS calcd for $[\mathrm{M}+\mathrm{H}]^{+}: \mathrm{C}_{20} \mathrm{H}_{26} \mathrm{~N}_{4} \mathrm{O}_{3} \mathrm{~F}_{3} \mathrm{~m} / z$ 427.2, found 427.2.

$N-((S)-1-\{3-[4-((3-t r i f l u o r o m e t h y l)$ phenyl)piperazin-1-yl]propyl\}pyrrolidin-2,5-dion-yl)cyclohexanecarbox amide [9\{8,3\}]. Yield: $15 \mathrm{mg}(61 \%$ isolated yield) as a yellow oil following chromatographic purification over silica gel with $\mathrm{CH}_{2} \mathrm{Cl}_{2} / \mathrm{MeOH}(90: 7)$; initial LC/MS purity $61 \%, t_{\mathrm{R}}=1.66 \mathrm{~min}$. ${ }^{1} \mathrm{H}-\mathrm{NMR}$ (300 MHz, $\mathrm{CDCl}_{3}$ ): $\delta$ 1.42-1.54 (cluster, 12H), 2.01-2.09 (m, 1H), 2.13-2.18 (m, 2H), 2.61-2.68 (dd, $J=18.2 \mathrm{~Hz}, J=4.9 \mathrm{~Hz}, 1 \mathrm{H}), 3.06-3.12(\mathrm{~m}, 1 \mathrm{H}), 3.27-3.36(\mathrm{~m}, 4 \mathrm{H}), 3.56-3.71(\mathrm{~m}, 6 \mathrm{H}), 4.72-4.79(\mathrm{~m}$, 1H), 7.06-7.09 (d, $J=7.9 \mathrm{~Hz}, 1 \mathrm{H}), 7.12(\mathrm{~s}, 1 \mathrm{H}), 7.14-7.16(\mathrm{~d}, 1 \mathrm{H}), 7.20-7.23(\mathrm{~d}, J=7.7 \mathrm{~Hz}, 1 \mathrm{H})$, 7.38-7.44 (t, $J=7.9 \mathrm{~Hz}, 1 \mathrm{H})$. MS calcd for $[\mathrm{M}+\mathrm{H}]^{+}: \mathrm{C}_{25} \mathrm{H}_{34} \mathrm{~N}_{4} \mathrm{O}_{3} \mathrm{~F}_{3} m / z$ 495.2, found 495.1.

$N-((S)-1-\{4-[4-((3-t r i f l u o r o m e t h y l)$ phenyl)piperazin-1-yl]butyl\}pyrrolidin-2,5-dion-yl)cyclopentanecarbox amide [9\{9,2\}]. Yield: $17 \mathrm{mg}(69 \%$ isolated yield) as a yellow oil following chromatographic purification over silica gel with $\mathrm{CH}_{2} \mathrm{Cl}_{2} / \mathrm{MeOH}(95: 5)$; initial LC/MS purity $51 \%, t_{\mathrm{R}}=1.60 \mathrm{~min}$. ${ }^{1} \mathrm{H}-\mathrm{NMR}$ (500 MHz, $\left.\mathrm{CD}_{3} \mathrm{OD} / \mathrm{CDCl}_{3}\right): \delta 1.54-1.61(\mathrm{~m}, 2 \mathrm{H}), 1.65-1.78(\mathrm{~m}, 5 \mathrm{H}), 1.80-1.97(\mathrm{~m}, 5 \mathrm{H}), 2.58-2.70(\mathrm{~m}$, 1H), $2.77(\mathrm{dd}, J=17.9 \mathrm{~Hz}, J=5.4 \mathrm{~Hz}, 1 \mathrm{H}), 2.99-3.21(\mathrm{~m}, 4 \mathrm{H}), 3.36-3.79(\mathrm{~m}, 9 \mathrm{H}), 4.59(\mathrm{~m}, 1 \mathrm{H}), 7.08$ (d, $J=8.2 \mathrm{~Hz}, 1 \mathrm{H}), 7.12(\mathrm{~s}, 1 \mathrm{H}), 7.21(\mathrm{~d}, J=7.6 \mathrm{~Hz}, 1 \mathrm{H}), 7.41(\mathrm{t}, J=7.9 \mathrm{~Hz}, 1 \mathrm{H}), 7.62(\mathrm{~d}, J=7.2 \mathrm{~Hz}, 1 \mathrm{H})$. ${ }^{13} \mathrm{C}-\mathrm{NMR}\left(500 \mathrm{MHz}, \mathrm{CD}_{3} \mathrm{OD} / \mathrm{CDCl}_{3}\right): \delta 20.1,24.3,26.0,30.3,35.6,37.5,44.9,46.5,48.8,51.7,56.6$, $113.7,118.2,119.9,122.9,124.0\left(\mathrm{q},{ }^{1} J_{\mathrm{CF}}=272 \mathrm{~Hz}\right), 125.1,130.1,132.4,149.7,175.2,176.9 . \mathrm{HRMS}$ calcd for $[\mathrm{M}+\mathrm{H}]^{+}: \mathrm{C}_{25} \mathrm{H}_{34} \mathrm{~N}_{4} \mathrm{O}_{3} \mathrm{~F}_{3} \mathrm{~m} / z$ 495.2578, found 495.2575.

$N-((S)-1-\{4-[4-((3-t r i f l u o r o m e t h y l)$ phenyl)piperazin-1-yl]butyl\}pyrrolidin-2,5-dion-3-yl)cyclohexane carboxamide [9\{9,3\}]. Yield: $12 \mathrm{mg}(46 \%$ isolated yield) as a yellow oil following chromatographic purification over silica gel with $\mathrm{CH}_{2} \mathrm{Cl}_{2} / \mathrm{MeOH}$ (90:7); initial LC/MS purity $62 \%, t_{\mathrm{R}}=1.67 \mathrm{~min}$. ${ }^{1} \mathrm{H}-\mathrm{NMR}\left(300 \mathrm{MHz}, \mathrm{CDCl}_{3}\right): \delta 1.15-1.42$ (cluster, 8H), 1.64-1.86 (m, 4H), 2.06-2.18 (m, 3H), 2,56 (br s, 4H), 2.61-2.69 (dd, $J=18.2 \mathrm{~Hz}, J=4.9 \mathrm{~Hz}, 1 \mathrm{H}), 2.99-3.12(\mathrm{q}, 1 \mathrm{H}), 3.27-3.35(\mathrm{~m}, 2 \mathrm{H}), 3.56-3.75$ (m, 6H), 4.65-4.73 (m, 1H), 7.06-7.08 (d, $J=8.2 \mathrm{~Hz}, 2 \mathrm{H}), 7.11(\mathrm{~s}, 1 \mathrm{H}), 7.20-7.24(\mathrm{~m}, 1 \mathrm{H}), 7.38-7.42$ $(\mathrm{t}, J=8.2 \mathrm{~Hz}, 1 \mathrm{H})$. MS calcd for $[\mathrm{M}+\mathrm{H}]^{+}: \mathrm{C}_{26} \mathrm{H}_{36} \mathrm{~N}_{4} \mathrm{O}_{3} \mathrm{~F}_{3} \mathrm{~m} / z$ 509.2, found 509.3. 
$N-((S)-1-\{4-[4-((3-t r i f l u o r o m e t h y l)$ phenyl)piperazin-1-yl]butyl\} pyrrolidin-2,5-dion-yl)benzamide $\quad[9\{9,4\}]$. Yield: $11 \mathrm{mg}$ (44\% isolated yield) as a yellow oil following chromatographic purification over silica gel with $\mathrm{CH}_{2} \mathrm{Cl}_{2} / \mathrm{MeOH}$ (92:8): initial LC/MS purity 40\%, $t_{\mathrm{R}}=1.62 \mathrm{~min} .{ }^{1} \mathrm{H}-\mathrm{NMR}$ (500 MHz, $\left.\mathrm{CD}_{3} \mathrm{OD} / \mathrm{CDCl}_{3}\right): \delta 1.68-1.80(\mathrm{~m}, 1 \mathrm{H}), 1.86-1.99(\mathrm{~m}, 3 \mathrm{H}), 2.98(\mathrm{dd}, J=17.9 \mathrm{~Hz}, J=5.8 \mathrm{~Hz}, 1 \mathrm{H})$, 3.07-3.24 (m, 4H), 3.38-3.73 (m, 9H), $4.85(\mathrm{~m}, 1 \mathrm{H}), 7.03(\mathrm{~d}, J=8.4 \mathrm{~Hz}, 1 \mathrm{H}), 7.06(\mathrm{~s}, 1 \mathrm{H}), 7.21(\mathrm{~d}$, $J=7.6 \mathrm{~Hz}, 1 \mathrm{H}), 7.37-7.44(\mathrm{~m}, 3 \mathrm{H}), 7.51(\mathrm{t}, J=7.4 \mathrm{~Hz}, 1 \mathrm{H}), 7.88(\mathrm{~d}, J=7.5 \mathrm{~Hz}, 2 \mathrm{H}), 8.42(\mathrm{~d}, J=7.5 \mathrm{~Hz}$, $1 \mathrm{H}) .{ }^{13} \mathrm{C}-\mathrm{NMR}\left(500 \mathrm{MHz}, \mathrm{CD}_{3} \mathrm{OD} / \mathrm{CDCl}_{3}\right): \delta 19.9,24.1,35.3,46.4,50.1,51.6,56.4,118.1,119.8$, $124.1\left(\mathrm{q},{ }^{1} J_{\mathrm{CF}}=272 \mathrm{~Hz}\right), 127.3,128.5,129.9,132.4,149.6,175.1$. HRMS calcd for $[\mathrm{M}+\mathrm{H}]^{+}$: $\mathrm{C}_{26} \mathrm{H}_{30} \mathrm{~N}_{4} \mathrm{O}_{3} \mathrm{~F}_{3} m / z$ 503.2265, found 503.2242.

$N-((S)-1-\{4-[4-((3-t r i f l u o r o m e t h y l)$ phenyl)piperazin-1-yl]butyl\}pyrrolidin-2,5-dion-3-yl)-2-(bicyclo[2.2.1] heptan-2-yl)acetamide [9\{9,5\}]. Yield: $15 \mathrm{mg}$ (57\% isolated yield) following chromatographic purification over silica gel with $\mathrm{CH}_{2} \mathrm{Cl}_{2} / \mathrm{MeOH}$ (90:10): initial LC/MS purity $59 \%, t_{\mathrm{R}}=1.78 \mathrm{~min}$. ${ }^{1} \mathrm{H}-\mathrm{NMR}\left(\mathrm{CDCl}_{3}\right) \delta 1.07-1.28(\mathrm{~m}, 6 \mathrm{H}), 1.47-1.52(\mathrm{~m}, 2 \mathrm{H}) 1.60(\mathrm{~m}, 1 \mathrm{H}), 1.80-2.01(\mathrm{~m}, 4 \mathrm{H}), 2.06-2.09$ $(\mathrm{m}, 1 \mathrm{H}), 2.17-2.23(\mathrm{~m}, 2 \mathrm{H}), 2.67-2.76(\mathrm{~s}, 1 \mathrm{H}), 2.97-3.13(\mathrm{~m}, 6 \mathrm{H}), 3.23-3.37(\mathrm{~m}, 4 \mathrm{H}), 3.61-3.69(\mathrm{~m}$, $4 \mathrm{H}), 4.65-4.82(\mathrm{~m}, 1 \mathrm{H}$,$) 7.06-7.12 (m, 2H), 7.20-7.26 (t, 1H), 7.34-7.43 (m, 2H). MS calcd for [\mathrm{M}+\mathrm{H}]^{+}$ $\mathrm{C}_{29} \mathrm{H}_{37} \mathrm{~N}_{4} \mathrm{O}_{3} \mathrm{~F}_{3} m / z$ 535.3, found 535.4.

$N-((S)-1-\{4-[4-((3-t r i f l u o r o m e t h y l)$ phenyl)piperazin-1-yl]butyl\}pyrrolidin-2,5-dion-yl)-1-adamatane carboxamide [9\{9,6\}]. Yield: $22 \mathrm{mg}$ (78\% isolated yield) as a yellow oil following chromatographic purification over silica gel with $\mathrm{CH}_{2} \mathrm{Cl}_{2} / \mathrm{OH}$ (95:5): Initial LC/MS purity $56 \%, t_{\mathrm{R}}=1.85 \mathrm{~min} .{ }^{1} \mathrm{H}-\mathrm{NMR}$ (500 MHz, $\left.\mathrm{CD}_{3} \mathrm{OD} / \mathrm{CDCl}_{3}\right): \delta 1.61-1.68(\mathrm{~m}, 3 \mathrm{H}), 1.69-1.77(\mathrm{~m}, 4 \mathrm{H}), 1.78-1.95(\mathrm{~m}, 9 \mathrm{H}), 2.01(\mathrm{~s}, 3 \mathrm{H})$, $2.78(\mathrm{dd}, J=17.8 \mathrm{~Hz}, J=5.5 \mathrm{~Hz}, 1 \mathrm{H}), 2.99(\mathrm{dd}, J=17.8 \mathrm{~Hz}, J=9.1 \mathrm{~Hz}, 1 \mathrm{H}), 3.04-3.25(\mathrm{~m}, 3 \mathrm{H})$, 3.30-3.77 (m, 9H), $4.41(\mathrm{~m}, 1 \mathrm{H}), 7.07$ (d, $J=8.5 \mathrm{~Hz}, 1 \mathrm{H}), 7.11(\mathrm{~s}, 1 \mathrm{H}), 7.19$ (d, $J=7.7 \mathrm{~Hz}, 1 \mathrm{H}), 7.40$ $(\mathrm{t}, J=7.9 \mathrm{~Hz}, 1 \mathrm{H}) .{ }^{13} \mathrm{C}-\mathrm{NMR}\left(500 \mathrm{MHz}, \mathrm{CD}_{3} \mathrm{OD} / \mathrm{CDCl}_{3}\right): \delta 19.9,24.2,27.9,35.1,36.2,37.5,38.8$, $40.4,46.4,48.9,51.4,56.2,113.5,117.9,119.7,122.8,123.9$ (q, $\left.{ }^{1} J_{\mathrm{CF}}=272 \mathrm{~Hz}\right), 124.9,129.9,131.7$, 149.7, 175.1, 176.7, 179.1. HRMS calcd for $[\mathrm{M}+\mathrm{H}]^{+}: \mathrm{C}_{30} \mathrm{H}_{40} \mathrm{~N}_{4} \mathrm{O}_{3} \mathrm{~F}_{3} \mathrm{~m} / z$ 561.3047, found 561.3024.

1-(Benzoyl)-N-\{3-[4-((3-trifluoromethyl)phenyl)piperazin-1-yl]propyl\}-L-prolinamide $\quad[\mathbf{1 0}\{8,4\}] . \quad$ Yield $14.5 \mathrm{mg}(61 \%$ isolated yield $)$ following chromatographic purification over silica gel with $\mathrm{CH}_{2} \mathrm{Cl}_{2} / \mathrm{MeOH}$ (92:8): Initial LC/MS purity 93\%, $t_{\mathrm{R}}=1.58 \mathrm{~min} .{ }^{1} \mathrm{H}-\mathrm{NMR}\left(300 \mathrm{MHz}, \mathrm{CDCl}_{3}\right): \delta 1.25-1.28$ (m, 3H), 1.77-1.85 (m, 2H), 2.02-2.09 (m, 2H), 2.59-2.62 (m, 6H), $3.25(\mathrm{~m}, 4 \mathrm{H}), 3.38-3.40(\mathrm{~m}, 2 \mathrm{H})$, $3.60(\mathrm{~m}, 1 \mathrm{H}), 4.65(\mathrm{t}, J=7.5 \mathrm{~Hz}, 1 \mathrm{H}), 7.02-7.08(\mathrm{~m}, 4 \mathrm{H}), 7.34(\mathrm{~m}, 1 \mathrm{H}), 7.40-7.42(\mathrm{~d}, 4 \mathrm{H}), 7.53$ (br s, 1H). MS calcd for $[\mathrm{M}+\mathrm{H}]^{+}: \mathrm{C}_{26} \mathrm{H}_{32} \mathrm{~N}_{4} \mathrm{O}_{2} \mathrm{~F}_{3} \mathrm{~m} / z$ 489.2, found 489.6.

1-(Adamantylcarbonyl)-N-\{3-[4-((3-trifluoromethyl)phenyl)piperazin-1-yl]propyl\}-L-prolinamide [10 $\{8,6\}]$. Yield: $13 \mathrm{mg}$ (47\% isolated yield) following chromatographic purification over silica gel with $\mathrm{CH}_{2} \mathrm{Cl}_{2} / \mathrm{MeOH}$ (92:8): Initial LC/MS purity $86 \%, t_{\mathrm{R}}=1.90 \mathrm{~min} .{ }^{1} \mathrm{H}-\mathrm{NMR}\left(300 \mathrm{MHz}, \mathrm{CDCl}_{3}\right): \delta 1.25-1.28$ (m, 4H), 1.67-1.72 (m, 8H), 1.82-1.95 (m, 2H), 1.99-2.15 (m, 4H), 2.17-2.18 (m, 1H), 2.59 (br s, 4H), 2.65 (br s, 6H), 3.26-3.35 (m, 4H), 3.72-3.83 (m, 2H), 4.56-4.58 (m, 1H), 7.04-7.10 (m, 3H), 7.31$7.32(\mathrm{t}, 1 \mathrm{H}), 7.34-7.37(\mathrm{~m}, 1 \mathrm{H})$. MS calcd for $[\mathrm{M}+\mathrm{H}]^{+}: \mathrm{C}_{30} \mathrm{H}_{42} \mathrm{~N}_{4} \mathrm{O}_{2} \mathrm{~F}_{3} m / z$ 547.3, found 547.4. 
1-(Cyclopentylcarbonyl)-N-\{4-[4-((3-trifluoromethyl)phenyl)piperazin-1-yl]butyl\}-L-prolinamide [10 $\{9,2\}]$. Yield: $12 \mathrm{mg}$ (49\% isolated yield) as a yellow oil following chromatographic purification over silica gel with $\mathrm{CH}_{2} \mathrm{Cl}_{2} / \mathrm{MeOH}(92: 8)$ : Initial LC/MS purity $83 \%, t_{\mathrm{R}}=1.60 \mathrm{~min} .{ }^{1} \mathrm{H}-\mathrm{NMR}\left(500 \mathrm{MHz}, \mathrm{CDCl}_{3}\right)$ : $\delta 1.54-1.64(\mathrm{~m}, 4 \mathrm{H}), 1.65-1.79(\mathrm{~m}, 4 \mathrm{H}), 1.80-1.89(\mathrm{~m}, 4 \mathrm{H}), 1.91-2.01(\mathrm{~m}, 2 \mathrm{H}), 2.02-2.15(\mathrm{~m}, 1 \mathrm{H})$, 2.21-2.29 (m, 1H), 2.77-2.89 (m, 1H), 2.9-3.18 (m, 4H), 3.19-3.35 (m, 3H), 3.37-3.45 (m, 1H), 3.47-3.58 (m, 2H), 3.59-3.78 (m, 4H), $4.47(\mathrm{dd}, J=8.0 \mathrm{~Hz}, J=3.0 \mathrm{~Hz}, 1 \mathrm{H}), 7.06(\mathrm{dd}, J=8.3 \mathrm{~Hz}, J=2.3 \mathrm{~Hz}$, $1 \mathrm{H}), 7.11(\mathrm{~m}, 1 \mathrm{H}), 7.17-7.25(\mathrm{~m}, 2 \mathrm{H}), 7.39(\mathrm{t}, J=8.0 \mathrm{~Hz}, 1 \mathrm{H}) .{ }^{13} \mathrm{C}-\mathrm{NMR}\left(500 \mathrm{MHz}, \mathrm{CDCl}_{3}\right): \delta 20.7$, 24.9, 26.0, 26.3, 28.2, 29.6, 30.1, 38.0, 42.9, 46.5, 47.5, 51.4, 56.5, 60.2, 113.5, 119.7, 122.9, 124.0 (q, $\left.{ }^{1} J_{\mathrm{CF}}=272 \mathrm{~Hz}\right), 125.1,129.9,131.8,149.8,172.4,176.6$. HRMS calcd for $[\mathrm{M}+\mathrm{H}]^{+}: \mathrm{C}_{26} \mathrm{H}_{38} \mathrm{~N}_{4} \mathrm{O}_{2} \mathrm{~F}_{3} \mathrm{~m} / z$ 495.2941, found 495.2936.

1-(Benzoyl)-N-\{4-[4-((3-trifluoromethyl)phenyl)piperazin-1-yl]butyl\}-L-prolinamide [10 $\{9,4\}]$. Yield: $14 \mathrm{mg}$ (56\% isolated yield) as a yellow oil following chromatographic purification over silica gel with $\mathrm{CH}_{2} \mathrm{Cl}_{2} / \mathrm{MeOH}$ (92:8): Initial LC/MS purity $89 \%, t_{\mathrm{R}}=1.58 \mathrm{~min} .{ }^{1} \mathrm{H}-\mathrm{NMR}\left(500 \mathrm{MHz}, \mathrm{CDCl}_{3}\right): \delta 1.57-1.71$ $(\mathrm{m}, 2 \mathrm{H}), 1.79-1.98(\mathrm{~m}, 3 \mathrm{H}), 1.99-2.09(\mathrm{~m}, 1 \mathrm{H}), 2.13-2.30(\mathrm{~m}, 2 \mathrm{H}), 2.69-2.94(\mathrm{~m}, 2 \mathrm{H}), 3.01-3.42(\mathrm{~m}$, $8 \mathrm{H}), 3.46-3.62(\mathrm{~m}, 3 \mathrm{H}), 3.67-3.76(\mathrm{~m}, 1 \mathrm{H}), 4.61(\mathrm{t}, J=7.5 \mathrm{~Hz}, 1 \mathrm{H}), 6.88-6.99(\mathrm{~m}, 2 \mathrm{H}), 7.17(\mathrm{~d}$, $J=7.7 \mathrm{~Hz}, 1 \mathrm{H}), 7.30(\mathrm{~m}, 1 \mathrm{H}), 7.33-7.47(\mathrm{~m}, 4 \mathrm{H}), 7.61(\mathrm{~d}, J=6.9 \mathrm{~Hz}, 2 \mathrm{H}) .{ }^{13} \mathrm{C}-\mathrm{NMR}(500 \mathrm{MHz}$, $\left.\mathrm{CDCl}_{3}\right): \delta 20.4,25.7,25.9,28.9,38.0,46.2,50.8,51.5,56.5,60.9,113.3,115.4,117.7,119.6,122.9$, $124.0\left(\mathrm{q},{ }^{1} J_{\mathrm{CF}}=272 \mathrm{~Hz}\right), 125.1,127.5,128.4,129.8,130.6,131.7,135.9,149.8,162.3,170.5,172.3$. HRMS calcd for $[\mathrm{M}+\mathrm{H}]^{+}: \mathrm{C}_{27} \mathrm{H}_{34} \mathrm{~N}_{4} \mathrm{O}_{2} \mathrm{~F}_{3} m / z$ 503.2628, found 503.2629.

1-((Bicyclo[2.2.1] heptan-2-yl)acetyl)-N-\{4-[4-((3-trifluoromethyl)phenyl)piperazin-1-yl]butyl\}-Lprolinamide [10 $\{9,5\}$ ]. Yield: $15 \mathrm{mg}$ (59\% isolated yield) following chromatographic purification over silica gel with $\mathrm{CH}_{2} \mathrm{Cl}_{2} / \mathrm{MeOH}$ (90:10): Initial LC/MS purity $91 \%, t_{\mathrm{R}}=1.80 \mathrm{~min} .{ }^{1} \mathrm{H}-\mathrm{NMR}(300 \mathrm{MHz}$, $\left.\mathrm{CDCl}_{3}\right) \delta(\mathrm{ppm}) 1.01-1.42(\mathrm{~m}, 3 \mathrm{H}), 1.25-1.32(\mathrm{~m}, 5 \mathrm{H}), 1.79(\mathrm{~m}, 1 \mathrm{H}), 1.93-1.98(\mathrm{~m}, 3 \mathrm{H}), 2.10-2.35$ $(\mathrm{m}, 4 \mathrm{H}), 2.44(\mathrm{~m}, 2 \mathrm{H}), 2.62(\mathrm{~m}, 4 \mathrm{H}), 3.25(\mathrm{~m}, 6 \mathrm{H}), 3.36-3.45(\mathrm{~m}, 3 \mathrm{H}), 4.54-4.57(\mathrm{~d}, J=7.9 \mathrm{~Hz}, 1 \mathrm{H})$, 7.04-7.10 (m, 3H), 7.31-7.33 (m, 1H), 7.35-7.38 (d, 1H); MS calcd for $[\mathrm{M}+\mathrm{H}]^{+} \mathrm{C}_{28} \mathrm{H}_{38} \mathrm{~N}_{4} \mathrm{O}_{3} \mathrm{~F}_{3} m / z$ 535.3, found 535.6.

1-(Adamantylcarbonyl)- $N$-\{4-[4-((3-trifluoromethyl)phenyl)piperazin-1-yl]butyl\}-L-prolinamide $\quad[\mathbf{1 0}\{9,6\}]$. Yield: $13 \mathrm{mg}$ (46\% isolated yield) as a yellow oil following chromatographic purification over silica gel with $\mathrm{CH}_{2} \mathrm{Cl}_{2} / \mathrm{MeOH}$ (92:8): Initial LC/MS purity 86\%, $t_{\mathrm{R}}=1.86$ min. ${ }^{1} \mathrm{H}-\mathrm{NMR}\left(500 \mathrm{MHz}, \mathrm{CDCl}_{3}\right)$ :

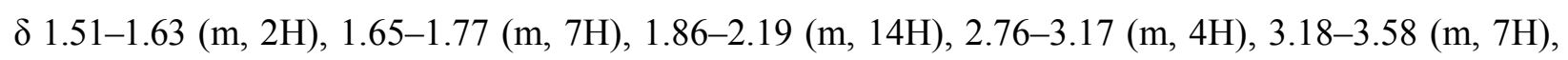
3.69-3.91 (m, 3H), $4.54(\mathrm{~m}, 1 \mathrm{H}), 6.80(\mathrm{~s}, 1 \mathrm{H}), 7.05(\mathrm{dd}, J=8.3 \mathrm{~Hz}, J=2.1 \mathrm{~Hz}, 1 \mathrm{H}), 7.10(\mathrm{~s}, 1 \mathrm{H}), 7.15$ (d, $J=7.7 \mathrm{~Hz}, 1 \mathrm{H}), 7.37(\mathrm{t}, J=8.0 \mathrm{~Hz}, 1 \mathrm{H}) .{ }^{13} \mathrm{C}-\mathrm{NMR}\left(500 \mathrm{MHz}, \mathrm{CD}_{3} \mathrm{OD} / \mathrm{CDCl}_{3}\right): \delta 14.0,20.9,26.5$, $28.1,36.4,38.1,41.8,47.1,48.5,51.8,56.9,60.4,62.4,112.9,119.3,122.9,124.1$ (q, $\left.{ }^{1} J_{\mathrm{CF}}=272 \mathrm{~Hz}\right)$, 125.1, 129.7, 131.6, 150.2, 173.1, 177.1. HRMS calcd for $\left[\mathrm{M}+\mathrm{H}^{+}: \mathrm{C}_{31} \mathrm{H}_{44} \mathrm{~N}_{4} \mathrm{O}_{2} \mathrm{~F}_{3} m / z\right.$ 561.3411, found 561.3409 .

\subsection{Solid-Phase Synthesis on BAL-PS Lanterns}

Reductive Amination Protocol. The Lanterns were divided into two groups and were placed in glass vials containing a suspension of sodium cyanoborohydride $\left(\left[\mathrm{NaBH}_{3} \mathrm{CN}\right]=100 \mathrm{mmol}\right)$ and the amine 
([Diversity reagent 2] $=250 \mathrm{mmol}$, Figure 4) in a $1 \%$ acetic acid in $3 \mathrm{~mL}$ of DMF. The reaction mixture was allowed to stand overnight at $60{ }^{\circ} \mathrm{C}$ and was then removed via a drilled adapter. The Lanterns were first washed with $10 \% \mathrm{AcOH}$ in DMF $(1 \times 5 \mathrm{~min})$ then with the standard washing protocol, and after allowed to dry in the open air.

\subsubsection{Secondary amine acylation protocol}

Two DMF solutions (2 mL) containing a Fmoc-protected amino acid and DIC each, were freshly prepared in a standard Schott flask before acylation $([\mathrm{Fmoc}-\mathrm{AA}-\mathrm{OH}]=200 \mathrm{mmol},[\mathrm{DIC}]=100 \mathrm{mmol})$, and were left for $10 \mathrm{~min}$ to form an active anhydride. Then the Lanterns were immersed in a preactivated solution and left overnight at room temperature. The solution was decanted, and the Lanterns were washed following the standard washing protocol. The acylation was repeated one time more for $4 \mathrm{~h}$.

\subsubsection{Standard Fmoc-deprotection protocol}

The Fmoc-deprotection step was carried out by immersing the Lanterns in a mixture of piperidine and DMF (20/80, v/v) for 60 min. A 100-mL standard flask, equipped with a drilled topper was used. After removal of the deprotection solution, the Lanterns were washed following the standard washing protocol.

\subsubsection{Standard acylation with carboxylic acids}

Six DMF solutions (2 mL), containing carboxylic acid (Figure 5: Diversity reagent 6), HBTU and DIEA each, were freshly prepared in a standard Schott flask before coupling $\left(\left[\mathrm{R}_{2}-\mathrm{CO}_{2} \mathrm{H}\right]=120 \mathrm{mmol}\right.$; $[\mathrm{HBTU}]=120 \mathrm{mmol}$; $[\mathrm{DIEA}]=240 \mathrm{mmol})$. The Lanterns were immersed for $2 \mathrm{~h}$ in the coupling solution at a room temperature. The solution was decanted, and the Lanterns were washed following the standard washing procedure. The procedure described above was repeated.

\subsubsection{Cleavage/cyclization protocol for succinimide derivatives formation}

Chemsets $7 \mathbf{a}$ and $7 \mathbf{b}$ were placed in glass vials containing a mixture of $\mathrm{TFA} / \mathrm{CHCl}_{3} / \mathrm{SOCl}_{2}(1 \mathrm{~mL}$, $50 / 50 / 1.5, \mathrm{v} / \mathrm{v} / \mathrm{v})$. The reaction was allowed to stand for 10 hours at $40{ }^{\circ} \mathrm{C}$. Afterwards, the reaction solution was removed under nitrogen flow. A $100 \mu \mathrm{L}$ portion of acetonitrile/water $(50 / 50$, v/v) containing a $0.1 \%$ TFA was poured into each tube to dissolve the samples. The samples were then frozen at $-80{ }^{\circ} \mathrm{C}$ and lyophilized.

\subsubsection{Cleavage of the proline derivatives off the lantern}

A $500 \mu \mathrm{L}$ aliquot of TFA was dispensed into individual glass tubes. Cleavage was carried out for $60 \mathrm{~min}$. The cleavage cocktail was removed from the tubes under nitrogen flow. A $100 \mu \mathrm{L}$ portion of acetonitrile/water $(50 / 50, \mathrm{v} / \mathrm{v})$ containing a $0.1 \%$ TFA was poured into each tube to dissolve the sample. Then the samples were frozen at $-80^{\circ} \mathrm{C}$ and lyophilized. 


\subsection{Analytical Data for 12 Library Members Synthesized on SynPhase Lanterns}

N-((S)-1-\{3-[4-((3-trifluoromethyl)phenyl)piperazin-1-yl]propyl\}pyrrolidin-2,5-dion-yl)cyclohexanecarboxamide $[9\{8,3\}]$. Yield: $5.1 \mathrm{mg}(47 \%)$ as a yellow oil following chromatographic purification over silica gel with $\mathrm{CH}_{2} \mathrm{Cl}_{2} / \mathrm{MeOH}(90: 10)$; initial LC/MS purity $74 \%, t_{\mathrm{R}}=1.66 \mathrm{~min}$. MS calcd for $[\mathrm{M}+\mathrm{H}]^{+}$: $\mathrm{C}_{25} \mathrm{H}_{34} \mathrm{~N}_{4} \mathrm{O}_{3} \mathrm{~F}_{3} m / z$ 495.2, found 495.1 .

$N-((S)-1-\{3-[4-((3-t r i f l u o r o m e t h y l)$ phenyl)piperazin-1-yl]propyl\}pyrrolidin-2,5-dion-yl)benzamide [9 $\{8,4\}]$. Yield: $3.8 \mathrm{mg}(35 \%)$ as a yellow oil following chromatographic purification over silica gel with $\mathrm{CH}_{2} \mathrm{Cl}_{2} / \mathrm{MeOH}$ (90:10); initial LC/MS purity $70 \%, t_{\mathrm{R}}=1.60 \mathrm{~min}$. MS calcd for $[\mathrm{M}+\mathrm{H}]^{+}$: $\mathrm{C}_{25} \mathrm{H}_{28} \mathrm{~N}_{4} \mathrm{O}_{3} \mathrm{~F}_{3} m / z$ 489.2, found 489.1 .

$N-((S)-1-\{3-[4-((3-t r i f l u o r o m e t h y l)$ phenyl)piperazin-1-yl]propyl\}pyrrolidin-2,5-dion-yl)-2-(bicyclo[2.2.1] heptan-2-yl)acetamide [9\{8,5\}]. Yield: $5.1 \mathrm{mg}(45 \%)$ as a yellow oil following chromatographic purification over silica gel with $\mathrm{CH}_{2} \mathrm{Cl}_{2} / \mathrm{MeOH}(90: 10)$; initial LC/MS purity $77 \%, t_{\mathrm{R}}=1.78 \mathrm{~min}$. MS calcd for $[\mathrm{M}+\mathrm{H}]^{+}: \mathrm{C}_{27} \mathrm{H}_{36} \mathrm{~N}_{4} \mathrm{O}_{3} \mathrm{~F}_{3} m / z$ 521.2, found 521.4 .

$N$-((S)-1-\{4-[4-((3-trifluoromethyl)phenyl)piperazin-1-yl]butyl\}pyrrolidin-2,5-dion-3-yl)cyclohexanecarboxamide [9 $\{9,3\}]$. Yield: $5.4 \mathrm{mg}$ (48\% isolated yield) as a yellow oil following chromatographic purification over silica gel with $\mathrm{CH}_{2} \mathrm{Cl}_{2} / \mathrm{MeOH}(90: 10)$; initial LC/MS purity $68 \%, t_{\mathrm{R}}=1.67$ min. MS calcd for $[\mathrm{M}+\mathrm{H}]^{+}: \mathrm{C}_{26} \mathrm{H}_{36} \mathrm{~N}_{4} \mathrm{O}_{3} \mathrm{~F}_{3} m / z$ 509.2, found 509.4.

$N-((S)-1-\{4-[4-((3-t r i f l u o r o m e t h y l)$ phenyl)piperazin-1-yl]butyl\}pyrrolidin-2,5-dion-yl)benzamide [9 $\{9,4\}]$. Yield: $4.9 \mathrm{mg}$ (44\% isolated yield) as a yellow oil following chromatographic purification over silica gel with $\mathrm{CH}_{2} \mathrm{Cl}_{2} / \mathrm{MeOH}(90: 10)$; initial LC/MS purity $64 \%, t_{\mathrm{R}}=1.62 \mathrm{~min}$. MS calcd for $[\mathrm{M}+\mathrm{H}]^{+}$: $\mathrm{C}_{26} \mathrm{H}_{30} \mathrm{~N}_{4} \mathrm{O}_{3} \mathrm{~F}_{3} m / z$ 503.2, found 503.3.

$N-((S)-1-\{4-[4-((3-t r i f l u o r o m e t h y l) p h e n y l)$ piperazin-1-yl]butyl\}pyrrolidin-2,5-dion-yl)-1-adamatanecarbox amide $[9\{9,6\}]$. Yield: $5.6 \mathrm{mg}(46 \%$ isolated yield $)$ as a yellow oil following chromatographic purification over silica gel with $\mathrm{CH}_{2} \mathrm{Cl}_{2} / \mathrm{MeOH}$ (90:10); initial LC/MS purity $75 \%, t_{\mathrm{R}}=1.85 \mathrm{~min}$. MS calcd for $[\mathrm{M}+\mathrm{H}]^{+}: \mathrm{C}_{30} \mathrm{H}_{40} \mathrm{~N}_{4} \mathrm{O}_{3} \mathrm{~F}_{3} m / z$ 561.3, found 561.4 .

1-(Cyclohexylcarbonyl)-N-\{3-[4-((3-trifluoromethyl)phenyl)piperazin-1-yl]propyl\}-L-prolinamide [10 $\{8,3\}]$. Yield: $6.3 \mathrm{mg}$ as a yellow oil (58\% isolated yield) following chromatographic purification over silica gel with $\mathrm{CH}_{2} \mathrm{Cl}_{2} / \mathrm{MeOH}(90: 10)$; initial LC/MS purity $96 \%, t_{\mathrm{R}}=1.69 \mathrm{~min}$. MS calcd for $[\mathrm{M}+\mathrm{H}]^{+}$: $\mathrm{C}_{26} \mathrm{H}_{38} \mathrm{~N}_{4} \mathrm{O}_{2} \mathrm{~F}_{3} m / z$ 495.3, found 495.4.

1-(Benzoyl)-N-\{3-[4-((3-trifluoromethyl)phenyl)piperazin-1-yl]propyl\}-L-prolinamide [10\{8,4\}]. Yield: 5.1 $\mathrm{mg}$ as a yellow oil (47\% isolated yield) following chromatographic purification over silica gel with $\mathrm{CH}_{2} \mathrm{Cl}_{2} / \mathrm{MeOH}$ (90:10); initial LC/MS purity $94 \%, t_{\mathrm{R}}=1.58 \mathrm{~min}$. MS calcd for $[\mathrm{M}+\mathrm{H}]^{+}$: $\mathrm{C}_{26} \mathrm{H}_{32} \mathrm{~N}_{4} \mathrm{O}_{2} \mathrm{~F}_{3} m / z$ 489.2, found 489.4.

1-((Bicyclo[2.2.1] heptan-2-yl)acetyl)-N-\{3-[4-((3-trifluoromethyl)phenyl)piperazin-1-yl]propyl\}-Lprolinamide [10 $\{8,5\}$ ]. Yield: $6.3 \mathrm{mg}$ as a yellow oil (55\% isolated yield) following chromatographic 
purification over silica gel with $\mathrm{CH}_{2} \mathrm{Cl}_{2} / \mathrm{MeOH}$ (90:10); initial LC/MS purity $96 \%, t_{\mathrm{R}}=1.81$ min; MS calcd for $[\mathrm{M}+\mathrm{H}]^{+} \mathrm{C}_{28} \mathrm{H}_{40} \mathrm{~N}_{4} \mathrm{O}_{2} \mathrm{~F}_{3} m / z$ 521.3, found 521.5.

1-(Cyclohexylcarbonyl)-N-\{4-[4-((3-trifluoromethyl)phenyl)piperazin-1-yl]butyl\}-L-prolinamide $\quad[\mathbf{1 0}\{9,3\}]$. Yield: $5.5 \mathrm{mg}$ as a yellow oil (49\% isolated yield) following chromatographic purification over silica gel with $\mathrm{CH}_{2} \mathrm{Cl}_{2} / \mathrm{MeOH}$ (90:10); initial LC/MS purity 97\%, $t_{\mathrm{R}}=1.68 \mathrm{~min}$. MS calcd for $[\mathrm{M}+\mathrm{H}]^{+}$: $\mathrm{C}_{27} \mathrm{H}_{40} \mathrm{~N}_{4} \mathrm{O}_{2} \mathrm{~F}_{3} m / z$ 509.3, found 509.2.

1-(Benzoyl)-N-\{4-[4-((3-trifluoromethyl)phenyl)piperazin-1-yl]butyl\}-L-prolinamide $\quad[\mathbf{1 0}\{9,4\}] . \quad$ Yield: $6.2 \mathrm{mg}$ as a yellow oil (56\% isolated yield) following chromatographic purification over silica gel with $\mathrm{CH}_{2} \mathrm{Cl}_{2} / \mathrm{MeOH}(90: 10)$; initial LC/MS purity $98 \%, t_{\mathrm{R}}=1.57 \mathrm{~min}$. MS calcd for $[\mathrm{M}+\mathrm{H}]^{+}$: $\mathrm{C}_{27} \mathrm{H}_{34} \mathrm{~N}_{4} \mathrm{O}_{2} \mathrm{~F}_{3} m / z$ 503.2, found 503.3.

1-(Adamantylcarbonyl)-N-\{4-[4-((3-trifluoromethyl)phenyl)piperazin-1-yl]butyl\}-L-prolinamide [10 $\{9,6\}]$. Yield: $6.5 \mathrm{mg}$ as a yellow oil (54\% isolated yield) following chromatographic purification over silica gel with $\mathrm{CH}_{2} \mathrm{Cl}_{2} / \mathrm{MeOH}$ (90:10); initial LC/MS purity $98 \%, t_{\mathrm{R}}=1.85 \mathrm{~min}$. MS calcd for $[\mathrm{M}+\mathrm{H}]^{+}$: $\mathrm{C}_{31} \mathrm{H}_{44} \mathrm{~N}_{4} \mathrm{O}_{2} \mathrm{~F}_{3} m / z$ 561.3, found 561.4.

Radioligand binding studies

The in vitro affinity for native serotonin $5-\mathrm{HT}_{1 \mathrm{~A}}$ and $5-\mathrm{HT}_{2 \mathrm{~A}}$ receptors was determined by inhibiting $\left[{ }^{3} \mathrm{H}\right]-8-\mathrm{OH}-D P A T$ (17 Ci/mmol; NEN Chemicals) and $\left[{ }^{3} \mathrm{H}\right]$-ketanserin (88 Ci/mmol; NEN Chemicals) binding to rat hippocampal and cortical membranes, respectively. Membrane preparation and a general assay procedure were carried out according to the previously published protocols [18]. Two compound concentrations were tested: 0.1 and $1 \mu \mathrm{M}$, each run in triplicate. The $K_{\mathrm{i}}$ values, estimated on the basis of three independent binding experiments $\mathrm{SEM} \leq 22 \%$.

\section{Conclusions}

In summary, we have successfully adapted a previous synthetic protocol to enable the synthesis of new chemical entities within the Distributed Drug Discovery (D3) project. As an outcome of student involvement we have disclosed a 24-member library of novel arylpiperazines, obtained on BAL-PSSynPhase Lanterns and on BAL-MBHA-PS resin. A subset of these was then tested on 5-HT $\mathrm{H}_{1 \mathrm{~A}}$ and $5-\mathrm{HT}_{2 \mathrm{~A}}$ receptors as potential agents for the treatment of CNS-directed disorders. The biological results indicated that introduction of the $m-\mathrm{CF}_{3}$ substituent in the phenylpiperazine fragments opens the possibility of obtaining dual $5-\mathrm{HT}_{1 \mathrm{~A}} / 5-\mathrm{HT}_{2 \mathrm{~A}}$ agents. While the biological testing is centralized, this combination of distributed synthesis with screening will enable a D3 network of students worldwide to participate, as part of their education, in the synthesis and testing of this class of biologically active compounds.

\section{Acknowledgements}

This study was partially supported by the Polish Ministry of Science and Higher Education (MNiSW), Grant Number N N405 378437. We also gratefully acknowledge funding by the National 
Institutes of Health (R01 GM028193) and the National Science Foundation (MRI CHE-0619254).

Radioligand binding experiments were financially supported by the grant PNRF-103-AI-1/07 from Norway through the Norwegian Financial Mechanism.

\section{References and Notes}

1. Borsini, F.; Evans, K.; Jason, K.; Rohde, F.; Alexander, B.; Pollentier, S. Pharmacology of Flibanserin. CNS Drug Rev. 2002, 8, 117-142.

2. Invernizzi, R.W.; Sacchetti, G.; Parini, S.; Acconcia, S.; Samanin, R. Flibanserin, a potential antidepressant drug, lowers 5-HT and raises dopamine and noradrenaline in the rat prefrontal cortex dialysate: Role of 5-HT 1 A receptors. Br. J. Pharmacol. 2003, 139, 1281-1288.

3. Jolly, E.; Clayton, A.; Thorp, J.; Lewis-D’Agostini, G. Design of Phase III pivotal trials of flibanserin in female Hypoactive Sexual Desire Disorder (HSDD). Sexologies 2008, 17, 133-134.

4. Zajdel, P.; Subra, G.; Bojarski, A.J.; Duszyńska, B.; Tatarczyńska, E.; Nikiforuk, A.; ChojnickaWójcik, E.; Pawłowski, M.; Martinez, J. Novel class of arylpiperazines containing $N$-acylated amino acids: Their synthesis, $5-\mathrm{HT}_{1 \mathrm{~A}}, 5-\mathrm{HT}_{2 \mathrm{~A}}$ receptor affinity, and in vivo pharmacological evaluation. Bioorg. Med. Chem. 2007, 15, 2907-2919.

5. López-Rodríguez, M.L.; Ayala, D.; Benhamú, B.; Morcillo, M.J.; Viso, A. Arylpiperazine derivatives acting at 5-HT(1A) receptors. Curr Med. Chem. 2002, 9, 443-469.

6. Lacivita, E.; Leopoldo, M.; Berardi, F.; Perrone, R. 5- $\mathrm{HT}_{1 \mathrm{~A}}$ receptor, an old target for new therapeutic agents. Curr Top Med. Chem. 2008, 8, 1024-1034.

7. Leopoldo, M. Serotonin(7) receptors 5-HT(7)Rs and their ligands. Curr. Med. Chem. 2004, 11, 629-661.

8. Zajdel, P.; Subra, G.; Verdie, P.; Bojarski, A.J.; Duszyńska, B.; Basista, K.; Obniska, J.; Martinez, J.; Pawłowski, M. The influence of an ethylene spacer on the 5- $\mathrm{HT}_{1 \mathrm{~A}}$ and $5-\mathrm{HT}_{2 \mathrm{~A}}$ receptor affinity of arylpiperazine derivatives of amides with $\mathrm{N}$-acylated amino acids and 3-differently substituted pyrrolidine-2,5-diones. Eur. J. Med. Chem. 2009, 44, 800-808.

9. Zajdel, P.; Subra, G.; Bojarski, A.J.; Duszyńska, B.; Pawłowski, M.; Martinez, J. A new class of arylpiperazine derivatives: The library synthesis on SynPhase lanterns and biological evaluation on serotonin 5-HT $1 \mathrm{~A}$ and 5-HT $2 \mathrm{~A}$ receptors. J. Comb. Chem. 2004, 6, 761-767.

10. Scott, W.L.; O'Donnell, M.J.; Distributed Drug Discovery, Part 1: Linking academia and combinatorial chemistry to find drug leads for developing world diseases. J. Comb. Chem. 2009, 11, 3-13.

11. Scott, W.L.; Alsina, J.; Audu, C.O.; Babaev, E.; Cook, L.; Dage, J.L.; Goodwin, L.A.; Martynow, J.G.; Matosiuk, D.; Royo, M.; et al. Distributed Drug Discovery, Part 2: Global rehearsal of alkylating agents for the synthesis of resin-bound unnatural amino acids and virtual D(3) catalog construction. J. Comb. Chem. 2009, 11, 14-33.

12. Scott, W.L.; Audu, C.O.; Dage, J.L.; Goodwin, L.A.; Martynow, J.G.; Platt, L.K.; Smith, J.G.; Strong, A.T.; Wickizer, K.; Woerly, E.M.; et al. Distributed Drug Discovery, Part 3: Using D(3) methodology to synthesize analogs of an anti-melanoma compound. J. Comb. Chem. 2009, 11, 34-43. 
13. Available from Leads Metal Products, PO Box 441186, Indianapolis, IN, 46244-1186 (larry@leadsmetal.com).

14. Maclean, D.; Martin, E.J. On the representation of combinatorial libraries. J. Comb. Chem. 2004, $6,1-11$.

15. Zajdel, P.; Subra, G.; Bojarski, A.J.; Duszyńska, B.; Pawłowski, M.; Martinez, J. Arylpiperazines with $\mathrm{N}$-acylated amino acids as $5-\mathrm{HT}_{1 \mathrm{~A}}$ receptor ligands. Bioorg. Med. Chem. Lett. 2006, 16, 3406-3410.

16. Zajdel, P.; Subra, G.; Bojarski, A.J.; Duszyńska, B.; Pawłowski, M.; Martinez, J. Parallel solid-phase synthesis and characterization of new sulfonamide and carboxamide proline derivatives as potential CNS agents. Bioorg. Med. Chem. 2005, 13, 3029-3035.

17. Available online: http://www.mimotopes.com (accessed on 26 January 2011).

18. Bojarski, A.J.; Cegła, M.T.; Charakchieva-Minol, S.; Mokrosz, M.J.; Maćkowiak, M.; Mokrosz, J.L. Structure-activity relationship studies of CNS agents. Part 9: 5- $\mathrm{HT}_{1 \mathrm{~A}}$ and 5- $\mathrm{HT}_{2}$ receptor affinity of some 2- and 3-substituted 1,2,3,4-tetrahydro-beta-carbolines. Pharmazie 1993, 48, 289-294.

Sample Availability: Contact the authors.

(C) 2011 by the authors; licensee MDPI, Basel, Switzerland. This article is an open access article distributed under the terms and conditions of the Creative Commons Attribution license (http://creativecommons.org/licenses/by/3.0/). 